\title{
CONTINOUS IMPROVEMENT AND APPLICATION OF QUALITY MANAGEMENT METHODS IN RAILWAY TRANSPORT PROCESSES
}

\author{
Vladimíra Štefancová, ${ }^{1}$ Anna Šatanová, ${ }^{2}$ Danka Harmanová ${ }^{3}$
}

\begin{abstract}
The basic principle of continuous improvement of each enterprise is to comprehend its particular transport processes. For better understanding and detailed analysis there are available lots of quality improvement toolkit. The relationship between consequence and potential causes can be monitored through various fundamental and specific tools. This article is oriented on train delay which belongs among the typical problems in the railway sector and is considered significant from the customer's perspective. The aim of this paper is to highlight the possible applications of quality management methods in the framework of the train delay issue. These delays influence a trains' punctuality and therefore it is important to identify most prevalent causing these problems reasons as well as to analyze them and propose solutions.
\end{abstract}

JEL Classification Numbers: M11, L15; DOI: http://dx.doi.org/10.12955/cbup.v5.967

Keywords: Flowchart, Ishikawa diagram, Pareto, delay causes, quality management, process

\section{Introduction}

With growing competition, a company is forced to increase the efficiency and productivity of its work and thus improve its final product or service. The implementation of new procedures and pioneering technique can positively change unresolved issues of any enterprise. The Six Sigma is considered an integral part of quality management with the aim of continual improvement. The principles of the Six Sigma methodology were applied in the past particularly in manufacturing, but nowadays there is a tendency also to use these methods in the services sector.

The goal output of rail transport is supplying the services in the required time frame as well as at the desired quality. This all depends on the quality of the resources, with regard to the utilized vehicles, properly scheduled timetable, individual operating processes as well as the staff willingness. This article emphasizes that the Six Sigma is an essential tool to increase customer satisfaction and simultaneously improve the quality of processes in railway transport. In order to achieve the desired results, it is necessary to focus on customer requirements and to become a customer-centered organization gradually. The aim of this article is to highlight the possible application of quality management methods with the goal of averting extraordinary circumstances such as train delay.

\section{The importance of acquisition and evaluation uniform data about train delays}

An important determinant for the customer when deciding about the use or non-use of services of the transport company becomes the quality of the provided services. Therefore, if we want to assess the quality of services effectively, it is necessary to take into account the factor of time, which is possible through dynamic models that take into account the procedural character of provided services (Nedeliaková \& Panák, 2015).

One of the goals of a railway company that operates in the area of services in railway transport is to obtain a lasting market share with a view of increasing it (Majerčák \& Nedeliak, 2010). This goal can be achieved through continuous monitoring and evaluation of the quality of the services provided, and taking into account the specific characteristics of all the parts of the transportation process (Nedeliaková \& Panák, 2016).

Abroad there exist several models of service quality, which are often concerned about this problem however, with different aspects, different from conditions of railway transport. It is therefore necessary to apply those tools of the quality model that will be suitable for rail transport. In regards to rating a company's service quality, it is important to take into mind the approaches of quality methods, and the techniques and models of quality, which connect objective and subjective aspects of the rating.

\footnotetext{
${ }^{1}$ Faculty of Operation and Economics of Transport and Communications, University of Žilina,

vladimira.stefancova@ fpedas.uniza.sk

${ }^{2}$ Department of Economics, Management and Marketing, International School of Management Slovakia, Prešov, satanova@ismpo.sk

${ }^{3}$ Faculty of Operation and Economics of Transport and Communications, University of Žilina,

danka.harmanova@fpedas.uniza.sk
} 
That was the initial impulse for creating a scientific research study, of which one of the results is this article (Nedeliaková, Sekulová, \& Nedeliak, 2015).

While solving any issue, accurate information is very important. In accordance with analyzing the current state it is essential to have constant data available intended for understanding the interrelations in order to improve the processes. Furthermore, the quality of information is correlated to the precise ability of the staff to collect data objectively and should be correctly entered into the information system (Majerčák \& Majerčák, 2015).

The main indicator of train delay is the punctuality of trains. This is measured regularly and represents the comparison between the time stated in the train timetable and the factual running time of a train. In general terms the range of train delay is usually reported in minutes. The continued provision of dynamic information on train movement are the basis for further in-depth analysis of the delay causes. The complete effect of train delays is considerable not only for passenger themselves but also for the Infrastructure Managers and for Railway Undertakings. (ŽSR, 2009).

One of the methods which can be applied in processes of railway transport is a flow diagram. The flowchart is a versatile tool for describing any process where the structure and sequence of activities is depicted by blocks showing operational activities and blocks showing decisions (Nenadál, 2008). It defines the continuity of the process and is used to gain a better understanding. Figure 1 shows a flowchart when the train is delayed. The initial sample consists of data about the passenger trains and there is a decision-making process if a train is delayed or not. If the train is late, the entrusted employee will assign to the train number its delay code. Otherwise, it is not necessary to deal with trains that arrive on time. Individual delay codes are defined in the Regulation (SR 1012) concerning operational information system (PIS) of infrastructure manager in Slovak Republic.

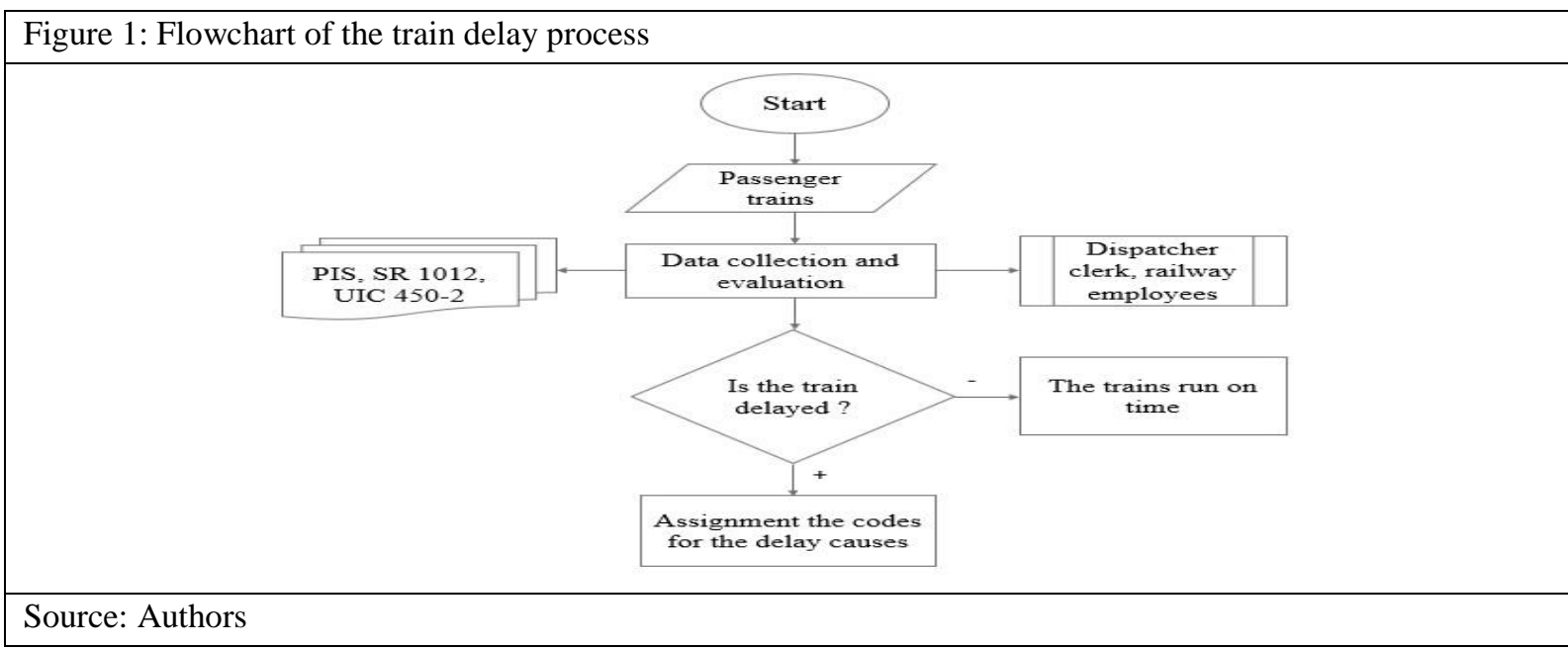

According to the circumstances, it is needful to properly identify the reasons for the delay and also it is recommended a coding system is used.

\section{Utilization of an Ishikawa and Pareto diagram to improving the quality of processes in the railway sector}

The requirements for quality service is increasing therefore it is necessary to look for new ways of improving quality that will meet international standards and reflect the increasing demands of customers (Nedeliaková \& Sekulová, 2016).

The implementation of processes is fundamental to create a successful and functioning enterprise. While the processes have constantly been changing, there must be connectivity between input and output (Fišer, 2014). That's the reason why particular elements, which enter into the process have to be continuously controlled.

The methods in an Ishikawa and Pareto diagram are included among the quality management methods for continuous improvement. These methods can also serve for monitoring problems in railway transport. The cause-and-effect diagram (Ishikawa diagram) is one of the fundamental tools used in the Six Sigma methodology. The line (spine) represents the effect and is typically labeled on one end as 
the head of the fish, each diagonal line (major bone) branching out from the spine corresponds to a major cause or group of causes (Brue, 2005).

The initial Ishikawa diagram consists of five groups (materials, machines, methods, measurements, men), but nowadays there are more used in a modified version such as management, environment and so on. The specification of delay reasons is a rather complicated creative process, which is usually carried out within a team where it is appropriate to use brainstorming or brainwriting. (Lusková, Hudáková, \& Buganová, 2013).

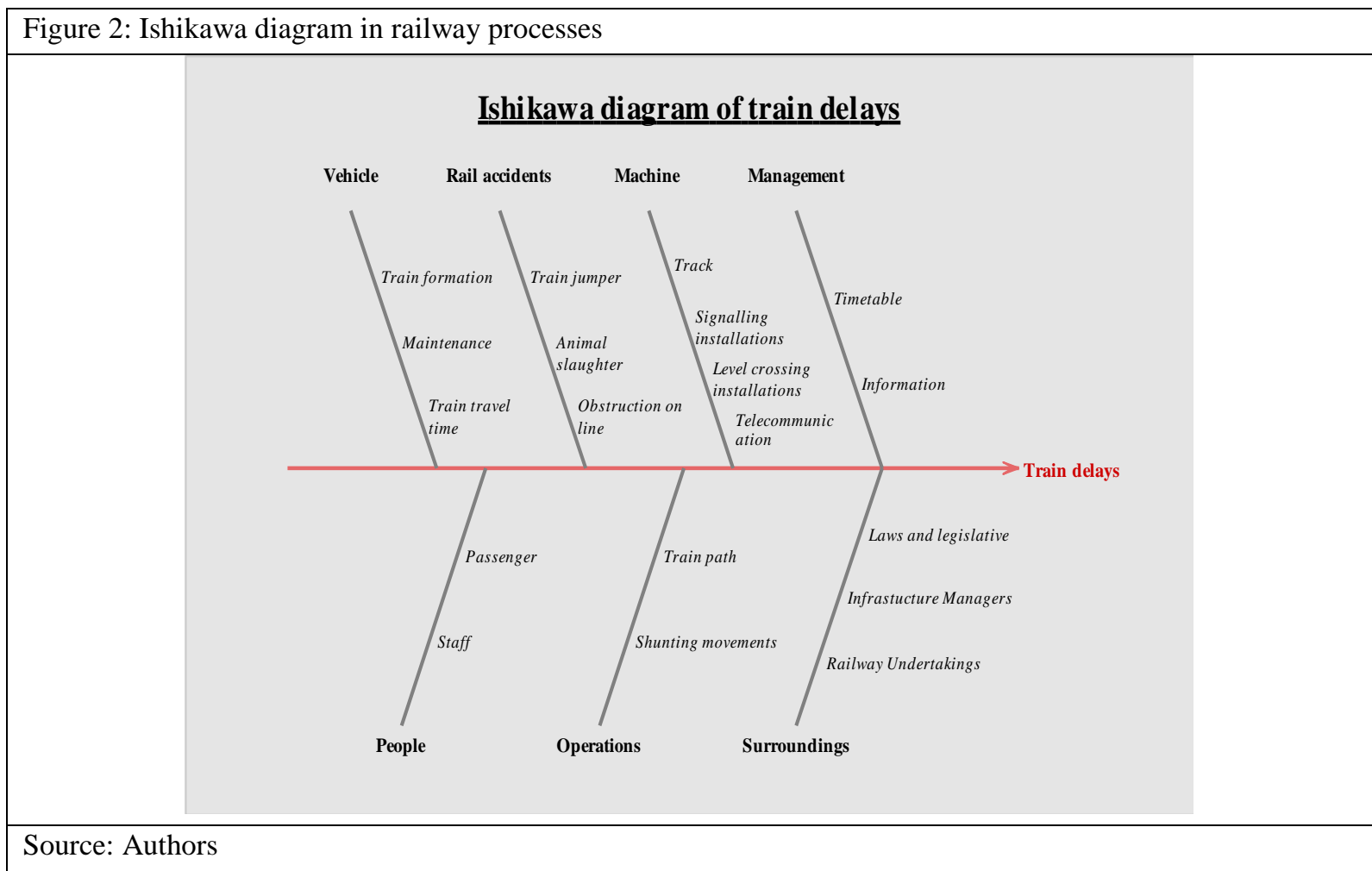

Figure 2 above represents using Ishikawa in practice for the conditions of railway transport from the point of view of an infrastructure manager and for railway undertakings. The purpose of the Ishikawa diagram is to lead a company in the direction of never-ending and continuous improvement which is pursued by continual application of eligible quality improvement tools. The research shows that in the conditions of railway transport, this diagram is able to describe an objective assessment of the quality within providing transport services (Nedeliaková, Sekulová, Nedeliak, \& Abramovic, 2016).

Illustratively it describes the main spine of the diagram, which is made up of seven basic parts:

- People - errors in personnel planning, disabled passengers, large amount of luggage, large number of passengers

- Operations - inadequate organization, sending a train to the wrong track, direction

- Surroundings - insufficient communication, delays caused by other infrastructure managers (previous or next), state bodies, the introduction of regulation UIC 450-2

- Vehicle - error in train composition, locomotive destruction, exceeding journey time

- Rail accidents - obstruction on line

- Machine - obsolete technical equipment, failures of signaling equipment, failures of ETCS and infrastructure components, defects in data-transmission system

- Management - mistakes in timetable compilation, late editing of timetables and other operating schedules

Another tool is the Pareto chart that can be used extensively for identifying the items that have the greatest cumulative effect in the process of railway transport. Pareto charts consist of bars, which represent the relative contribution of each cause or component of the problem and are arranged in a descending order (George, 2003). 
Statistical significance is analyzed by using the Pareto principle and that is visible through the Pareto diagram in Graph 1.

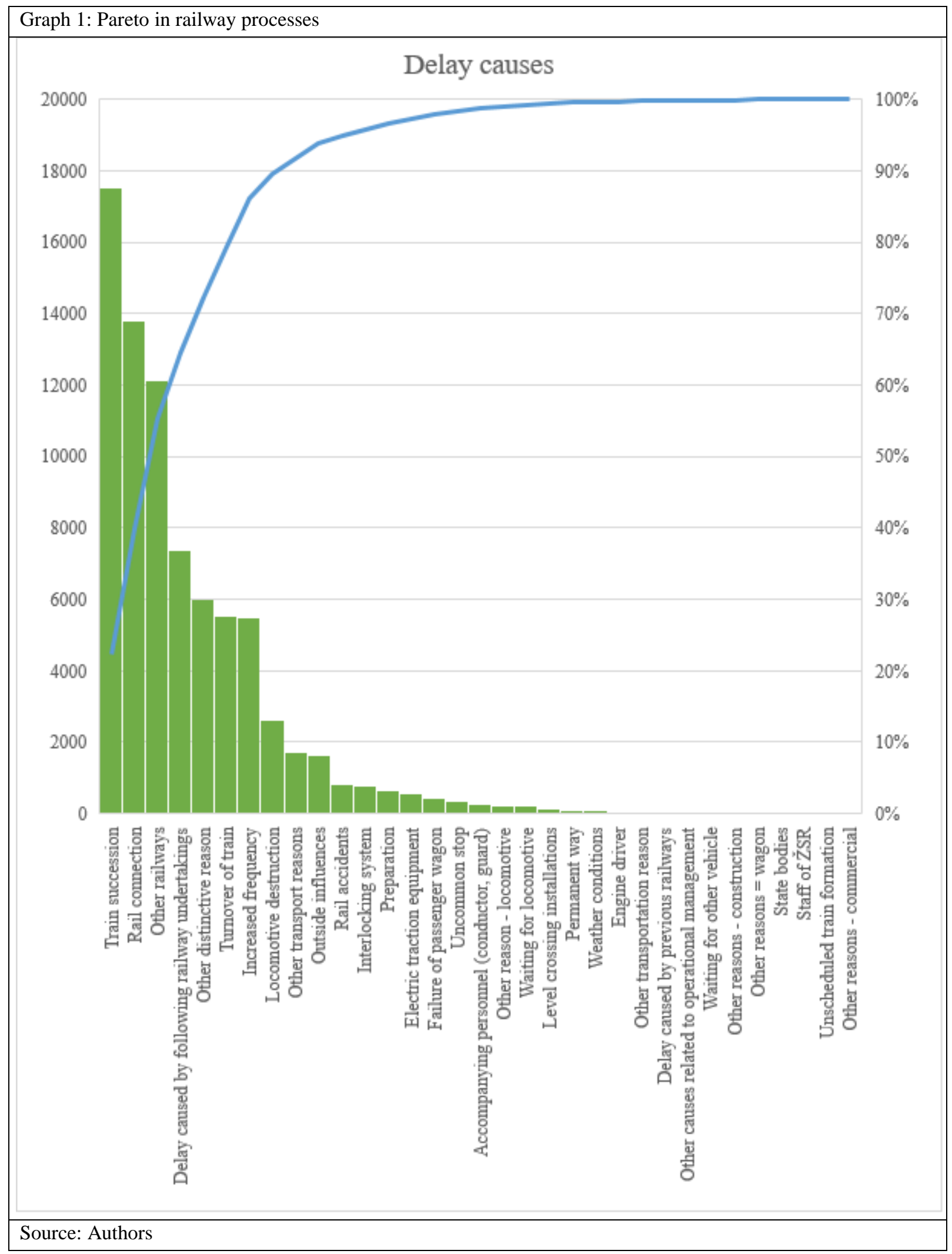

Graph 1. The data was obtained from the information system of ŽSR during March 2016. Approximately 80 percent of train delays are the result of only five main delay causes. The most prominent of them are train succession, rail connection, other railways and delay caused by following railway undertakings. Other steps for more detailed analysis can be using brainstorming with experts 
in the transport sector, that can offer an explanation for delays and why these causes are so numerous and often occurring.

\section{Conclusion}

The aim of each enterprise is to strengthen a competitive advantage. In any organization, the hidden downside or disadvantage can also occur in common operation. Oftentimes it may be related to lack of information as well as inadequate communication between departments. The solution to this problem involves finding an acceptable way to transmit the accurate data so as to achieve comparable results. Developing reliable data collection can take lots of time but successful process improvement are dependent on it. In connection with the use of certain methods of quality management can be recognized as important factors of train delay.

The conducted research shows that some of the quality methods are applicable to the processes in railway transport, regarding to train delay. These methods were chosen because it is completely transparent. The cause-and-effect diagram is dedicated for mapping processes and consequently the Pareto diagram can be used to analyze the possible delay causes. This study was focused on evaluating the available data from information systems in order to compare the various reasons for train delays.

\section{Acknowledgement}

This research was financially supported by the project KEGA 010ŽU-4/2017 New methods of teaching quality management in the study program Railway transport with a focus on optimization of extraordinary events in terms of customer orientation.

\section{References}

Brue, G. (2005). Six Sigma for Managers 24 Lessons to Understand and Apply Six Sigma Principles in Any Organization. New York: The McGraw-Hill Companies.

Fišer, R. (2014). Procesní řízení pro manažery. Praha: Grada Publishing, a.s.

George, M. L. (2003). Six Sigma for service. New York: McGraw-Hill.

Lusková, M., Hudáková, M., \& Buganová, K. (2013). Manažérstvo kvality a rizika. Žilina: EDIS-vydavatel’stvo Žilinskej univerzity.

Majerčák, J., \& Nedeliak, I. (2010). Practical experiences with modeling of IT systems and business processes. 6th Forum of Rail Transport, Bratislava: ŽSR, 81-84.

Majerčák, P., \& Majerčák, J. (2015). Logistics Indicators for Measuring Performance of Logistics System in the Company. 3rd International Conference on Education Reform and Management Innovation ERMI, Bangkok, Thailand: Information Engineering research Inst., 151-155.

Nedeliaková, E., \& Panák, M. (2015). New Trends in Process-Oriented Quality Management. 9th International Scientific Conference on Business Economics and Managent, Zvolen: Tech Univ Zvolen, 172-179.

Nedeliaková, E., \& Panák, M. (2016). Methodology for quality assessment within transportation chain. 1st International Conference Contemporary Issues in Theory and Practice of Management Location, Czestochowa: Univ Technol, Fac Management, 309-314.

Nedeliaková, E., \& Sekulová, J. (2016). Evaluation of quality in railway transport. Žilina: EDIS - vydavatel’ské centrum ŽU.

Nedeliaková, E., Sekulová, J., \& Nedeliak, I. (2015). Application of dynamic models as a new trend in quality management. 9th International Scientific Conference on Business Economics and Management, Zvolen: Tech Univ Zvolen, 180-186.

Nedeliaková, E., Sekulová, J., Nedeliak, I., \& Abramovic, B. (2016). Application od raymond fisk model in research of service quality. Communications, Žilina: University of Žilina, 11-14.

Nenadál Jaroslav, N. D. (2008). Moderní management jakosti. Praha: Management Press.

ŽSR, O. 4. (2009). SR 1012 Prevádzkový informačný systém. Bratislava: Železnice Slovenskej republiky. 